\title{
The vitamin $D$ activity of plasma of children with idiopathic hypercalcaemia
}

\author{
By W. F. J. CUTHBERTSON \\ Glaxo Research Ltd, Greenford, Middlesex \\ (Received 23 April 1963-Revised 21 fune 1963)
}

Similarities between idiopathic hypercalcaemia of infants and vitamin $\mathrm{D}$ intoxication have led to the suspicion that the former may be caused by giving needlessly large doses of vitamin $\mathrm{D}$ to children who are more than usually sensitive to its effects or who absorb it with unusual efficiency. This view has been strengthened by the rarity of idiopathic hypercalcaemia in the USA and in Sweden, countries in which the vitamin $\mathrm{D}$ intake of children used to be much less than in the UK (Morgan, Mitchell, Stowers \& Thomson, 1956).

In the USA Smith, Blizzard \& Harrison (1959) reported a serum vitamin D activity of 23 i.u./ml in one patient, and Fellers \& Schwartz $(1958 a, b)$ noted high activity, between 20 and $60 \mathrm{i} . \mathrm{u} . / \mathrm{ml}$, in three patients. These findings support the view that idiopathic hypercalcaemia may be caused by overdosage with vitamin $D$. On the other hand, Thomas, Morgan, Connor, Haddock, Bills \& Howard ( r 959) reported essentially normal vitamin D activities $(\mathrm{I}-3$ i.u. $/ \mathrm{ml}$ ) in samples of serums sent to the USA from patients in the UK. The work to be reported here was carried out further to investigate the condition in the UK.

\section{EXPERIMENTAL}

Samples. Samples of heparinized plasma, 5-10 ml, from patients suffering from idiopathic hypercalcaemia were tested, together with similar samples obtained at approximately the same time from control patients of about the same age and sex but not suffering from any abnormality of calcium or vitamin $\mathrm{D}$ metabolism. All diagnoses were made by the physicians and pathologists named in the acknowledgements, to whom I am deeply grateful for providing the plasma samples.

In one instance, serum samples from the hypercalcaemic patient and from the control were provided but this mistake is not thought to have affected the results, because in other experiments no significant differences could be detected between the vitamin $\mathrm{D}$ activity of serum and plasma from the same specimen of blood. All samples were frozen quickly (to prevent protein separation) and stored in the deep freeze until assayed. Tests not reported here have shown that storage in a deep freeze for a period of several months, with melting and immediate refreezing at monthly intervals, or storage for up to 14 days in the refrigerator $\left(4^{\circ}\right)$ does not lead to loss of vitamin D activity.

Livers from a child who died in idiopathic hypercalcaemia and from a control child dying from another condition were stored in the deep freeze until required. The livers were saponified by the method of E. Kodicek (personal communication). To each $5 \circ \mathrm{g}$ 
Table 1. Plasma vitamin D activity and serum calcium level of children suffering from mild idiopathic hypercalcaemia and of control children

(Numbers in parentheses denote days before $(-)$ or after $(+)$ transfer to diet low in $\mathrm{Ca}$ and vitamin D. NR, not recorded)

\begin{tabular}{|c|c|c|c|c|c|c|}
\hline Patient and sex & M.B., is & E.F., $\stackrel{9}{+}$ & M.P., $\hat{o}$ & H.K., ․ & G.S., $\hat{\jmath}$ & S.W., o. \\
\hline Date of birth & 14. iii. 62 & 9. ii. 59 & 27. iv. 61 & I3. xi. 61 & 17. iv. 61 & 9. ii. 59 \\
\hline $\begin{array}{l}\text { Date vitamin D } \\
\text { withdrawn }\end{array}$ & I. x. 62 & I4. X. 59 & 16. xi. 60 & I. X. 62 & $25 \cdot x \cdot 6 \mathrm{I}$ & II. i. 60 \\
\hline $\begin{array}{l}\text { Date of introduction } \\
\text { of diet low in } \\
\text { vitamin } \mathrm{D} \text { and } \mathrm{Ca}\end{array}$ & I. x. 62 & 30. x. 59 & 16. xi. 60 & I. $x .62$ & I. xii. 61 & 8. ii. 60 \\
\hline $\begin{array}{l}\text { Approximate daily } \\
\text { vitamin } \mathrm{D} \text { intake } \\
\text { before treatment } \\
\text { (i.u.) }\end{array}$ & 1350 & 2000 & $\begin{array}{l}\text { NR, } \\
\text { probably } \\
\text { rooo }\end{array}$ & 2500 & 1000 & $2000-3000$ \\
\hline $\begin{array}{l}\text { Serum } \mathrm{Ca} \text { at or near } \\
\text { date of diagnosis } \\
(\mathrm{mg} / 100 \mathrm{ml})\end{array}$ & $\begin{array}{l}12.9(-14) \\
10.8(-52)\end{array}$ & $13.0(0)$ & $11 \cdot 4(-5)$ & $13 \cdot 2(-4)$ & $11 \cdot 5(+36)$ & $\begin{array}{l}13(-80) \\
9 \cdot 8(0)\end{array}$ \\
\hline $\begin{array}{l}\text { Serum } \mathrm{Ca} \text { at or near } \\
\text { date of vitamin } \mathrm{D} \\
\text { assay }(\mathrm{mg} / 100 \mathrm{ml})\end{array}$ & $\begin{array}{l}12.9(-14) \\
10.8(+15)\end{array}$ & $13.0(0)$ & $\mathrm{IO}_{4}(+9)$ & $\begin{array}{r}9.4(+15) \\
10.7(+29)\end{array}$ & $\begin{array}{l}12 \cdot 9(+41) \\
12 \cdot 4(+43)\end{array}$ & - \\
\hline $\begin{array}{l}\text { Plasma vitamin } \mathrm{D} \\
\text { activity (i.u./ml) }\end{array}$ & $2 \cdot 9(-2)$ & $3 \cdot \circ(+3)$ & $2 \cdot 0(+7)$ & $2 \cdot I(+25)$ & $I \cdot 5(+42)$ & $1 \cdot 4(+140)$ \\
\hline $\begin{array}{l}\text { Plasma vitamin } \mathrm{D} \\
\text { activity of control } \\
\text { patient }(\mathrm{i} . \mathrm{u} . / \mathrm{ml})\end{array}$ & $2 \cdot 3$ & - & $3 \cdot 0$ & $3 \cdot 6$ & $1 \cdot 7$ & $I \cdot I$ \\
\hline
\end{tabular}

Mean plasma vitamin D activity of patients $2 \cdot 1$ i.u. $/ \mathrm{ml}$ and of controls $2 \cdot 3$ i.u. $/ \mathrm{ml}$.

\section{Table 2. Plasma vitamin $D$ activity and serum calcium level of children suffering from severe idiopathic hypercalcaemia and of control children}

(Numbers in parentheses denote days before $(-)$ or after $(+)$ transfer to diet low in Ca and vitamin D)

\begin{tabular}{|c|c|c|c|c|c|}
\hline Patient and sex & A. C., ?ִ & P.B., 5 & A.B., 0 & S.T., 3 & S.D., $q$ \\
\hline Date of birth & I5. v. $6 \mathrm{I}$ & I2. v. 59 & I7. iv. $6 \mathrm{I}$ & 26. ii. $6 \mathrm{I}$ & 26. iv. 59 \\
\hline Date vitamin $\mathrm{D}$ withdrawn & 25. xi. 61 & 12. xi. 60 & 7. i. 62 & I1. xi. 6I & I $7 . x \cdot 59$ \\
\hline $\begin{array}{l}\text { Date of introduction of diet low in } \\
\text { vitamin } \mathrm{D} \text { and } \mathrm{Ca}\end{array}$ & 25. xi. $6 \mathrm{r}$ & 9. xii. 60 & 7. i. 62 & 11. xi. 6 I & I7. X. 59 \\
\hline $\begin{array}{l}\text { Approximate daily vitamin } \mathrm{D} \text { intake } \\
\text { before treatment (i.u.) }\end{array}$ & 1500 & 1900 & 1000 & 3000 & 1700 \\
\hline $\begin{array}{l}\text { Serum calcium at or near date of } \\
\text { diagnosis }(\mathrm{mg} / \mathrm{l} 00 \mathrm{ml})\end{array}$ & $\begin{array}{l}15 \cdot 3(-15) \\
16 \cdot 1(-I I)\end{array}$ & $11 \cdot 7(+3)$ & $11 \cdot 4(-1)$ & $14.9(+3)$ & $14.7(0)$ \\
\hline $\begin{array}{l}\text { Serum calcium at or near date of } \\
\text { vitamin } D \text { assay }(\mathrm{mg} / \mathrm{1} 00 \mathrm{ml})\end{array}$ & $\begin{array}{l}\text { I6.I }(-11) \\
\text { II } 7(+9)\end{array}$ & $\mathrm{II} \cdot 8(+\mathrm{II})$ & $9 \cdot 5(+17)$ & $13 \cdot 4(+16)$ & $\begin{array}{l}8 \cdot 3(+190) \\
9 \cdot 2(+210)\end{array}$ \\
\hline Plasma vitamin D activity (i.u. $/ \mathrm{ml}$ ) & $\begin{array}{l}2 \cdot 0(0) \\
2 \cdot 0(+12)\end{array}$ & - $(+10)$ & $1 \cdot 7(+18)$ & $2 \cdot 0(+25)$ & $1 \cdot 0(+200)$ \\
\hline $\begin{array}{l}\text { Plasma vitamin } D \text { activity of } \\
\text { control paticnt (i.u./ml) }\end{array}$ & $2 \cdot 0,2 \cdot 0$ & $*$ & $1 \cdot 7$ & $2 \cdot 0$ & $1 \cdot 0$ \\
\hline
\end{tabular}

Mean plasma vitamin D activity of patients $\mathrm{I} \cdot 7 \mathrm{i} . \mathrm{u} . / \mathrm{ml}$ and of controls $\mathrm{I} \cdot 7 \mathrm{i} . \mathrm{u} . / \mathrm{ml}$.

- Statistical examination of the values from this assay showed that the vitamin D activity of the control and hypercalcaemic plasma did not differ significantly though the values were not sufficiently precise to permit a quantitative statement of vitamin $D$ activity. 
of liver were added $30 \mathrm{ml}$ absolute alcohol and $4 \mathrm{ml}$ saturated aqueous $\mathrm{KOH}$. The mixture was then heated for 30 min on a steam-bath and then allowed to cool. The digest was extracted four times with equal volumes of peroxide-free diethyl ether. The extracts were washed with water to eliminate alkali, dried over anhydrous sodium sulphate, evaporated and taken up in arachis oil. The extracts were diluted further with arachis oil and assayed by the routine line-test procedure as used for oily vitamin D preparations in these laboratories (International Union of Pure and Applied Chemistry, 1959) on forty-eight rats in each assay. The vitamin D activity of the plasma samples was also determined by the line-test rat assay method. Litters of four or eight rats were placed on the rachitogenic diet at 21 days of age. After 14 days they were divided into groups, each of at least six rats, matched for litter origin but otherwise randomly selected. The animals in two groups were each given, daily, either $0 \cdot \mathrm{I}$ or $0.2 \mathrm{ml}$ of a standard arachis oil solution containing 2 i.u. vitamin $\mathrm{D} / \mathrm{ml}$, those in the other groups being all given, daily, $0.1 \mathrm{ml}$ of arachis oil with either 0.05 or $0.1 \mathrm{ml}$ of the plasma sample. All doses were given orally by syringe for a ro-day period, at the end of which the animals were killed, the tibias were dissected, and the degree of rickets was assessed by the line-test procedure. The vitamin $\mathrm{D}$ activity of the test sample was then calculated in terms of the standard.

Table 3. Vitamin $D$ content of liver from a child with mild idiopathic hypercalcaemia and from a child not suffering from any known derangement of calcium or vitamin $D$ metabolism

\begin{tabular}{|c|c|c|}
\hline & Hypercalcaemic child & Control \\
\hline Weight of liver $(g)$ & I 75 & 136 \\
\hline $\begin{array}{l}\text { Total vitamin } D \text { activity and fiducial range } \\
(P=0.95) \text { (i.u./liver) }\end{array}$ & $120(50-150 \%)$ & $435(43-1300 \%)$ \\
\hline Vitamin D intake (i.u./day) & 3000 until I month before death & 3000 \\
\hline
\end{tabular}

Table 4. Plasma vitamin $D$ activity of children with different vitamin $D$ (ergocalciferol) intakes

\begin{tabular}{|c|c|c|c|}
\hline Child and sex & K.B., $q$ & P.H., o & M.P., \\
\hline $\begin{array}{l}\text { Age } \\
\text { Condition }\end{array}$ & $\begin{array}{l}\text { I5 months } \\
\text { Aminoaciduria }\end{array}$ & $\begin{array}{l}8 \text { years } \\
\text { Cystinosis }\end{array}$ & $\begin{array}{l}9 \text { years } \\
\text { Vitamin } D \\
\text { intoxication }\end{array}$ \\
\hline $\begin{array}{l}\text { Ergocalciferol dose (i.u./day) } \\
\text { Period of dosing before test } \\
\text { Plasma vitamin D (i.u./ml) }\end{array}$ & $\begin{array}{l}1000 \\
8 \text { months } \\
3\end{array}$ & $\begin{array}{l}20000 \\
6 \text { years } \\
\simeq 10\end{array}$ & $\begin{array}{l}150000 \\
20 \text { months } \\
>20\end{array}$ \\
\hline
\end{tabular}

RESULTS

The results obtained on examination of samples from six patients with the mild and five with the severe form of idiopathic hypercalcaemia are summarized in Tables I and 2 respectively, together with other relevant facts and the vitamin D activity of the samples from the control patients. 
Table 3 provides information on the liver samples, and Table 4 on the results obtained on samples from three children with precisely defined vitamin $D_{2}$ (ergocalciferol) intakes.

\section{DISCUSSION}

The results given in Tables $\mathrm{I}$ and 2 show that the vitamin $\mathrm{D}$ activity of all the samples examined fell within the range $1 \cdot 0-3 \cdot 6 \mathrm{i} . \mathrm{u} . / \mathrm{ml}$, which is in close agreement with results of determinations made by Thomas $e t$ al. (1959) on normal subjects. Further, they show that the values for patients with the severe or the mild form of the disease do not differ from each other or from those for the controls. One of the patients, H.K., was a twin, and her twin sister was used to provide a control plasma sample. Both children were brought up and fed in the same way and given the same vitamin supplements until admission of the affected twin to hospital, except that for some time before entering hospital the affected twin had a poorer appetite.

In only five instances were samples obtained when the patient had been on a diet free from vitamin $D$ for less than to days. It could therefore be argued that plasma vitamin $\mathrm{D}$ activity might originally have been high but that this activity had fallen in a number of the patients during the time they had been kept on the vitamin D-free regimen before assay. Had it been so, then the difference between the activities of samples from patients and controls should have been much greater for patients M. B., A.C., E.F., P.B. and M.P. than for the others who had been under treatment longer before examination. In fact, the values for these patients did not differ from those for their controls any more than did the others in this series.

Smith et al. (1959) and Fellers \& Schwartz (1958a,b) showed that the high serum vitamin $\mathrm{D}$ activity noted in their patients with idiopathic hypercalcaemia fell only slowly after they had been transferred to a vitamin D-free diet. Warkany, Guest \& Grabill (1942) and Thomas et al. (1959) have shown that serum vitamin D activity, once elevated by administration of vitamin $\mathrm{D}$, may take several months to return to normal. Thus if any of the patients in this series had had significantly elevated plasma vitamin $D$ activity before withdrawal of vitamin $D$, then this value would be expected still to have been higher than the control value for several months afterwards. In fact, significantly higher levels were not noted in any of the patients in this series, so that it is unlikely that the condition in these patients could have been associated with a high plasma vitamin $\mathrm{D}$ activity.

This conclusion is supported by the figures in Table 3, which show that the liver stores of a child who died in idiopathic hypercalcaemia were in fact smaller than those of a child of the same age who had been receiving about the same amount of vitamin $D$. The hypercalcaemic child had not been given any vitamin D for $\mathrm{I}$ month before death. This fact could explain the lower vitamin $D$ content of the liver, but the fact that the child was certainly suffering from idiopathic hypercalcaemia at death shows that a high vitamin D status is not necessary for demonstration of the condition. Unfortunately the vitamin D activity of the plasma could not be determined, but the liver vitamin $D$ activity, about $\mathrm{I}-2$ i.u./g, was not much different from that expected in plasma from children of this type. Devaney \& Munsell (1935) showed the vitamin D 
content of livers of sheep, cattle and pigs to be about $0.1-0.5 \mathrm{i} . \mathrm{u} . / \mathrm{g}$, which is somewhat lower than the activity of serum $\left(0.5^{-1}\right.$ i.u. $\left./ \mathrm{ml}\right)$ found in the same species by Warkany (1937). More recently Quarterman, Dalgarno \& Adam (1963) have shown in the pig that blood vitamin $\mathrm{D}$ activity is higher than that of the liver. Our findings may therefore indicate that in man, as in some other species, liver vitamin D stores are small, at least in individuals receiving moderate amounts of the vitamin.

Table 4 shows that 1000 i.u. vitamin $\mathrm{D} /$ day can maintain a plasma vitamin $\mathrm{D}$ activity of about 3 i.u. $/ \mathrm{ml}$, doses of $20000 \mathrm{i}$.u./day can cause a marked rise in the plasma vitamin $D$ activity, and administration of 150000 i.u./day causes a still further increase in plasma vitamin $\mathrm{D}$ activity. It appears that the plasma vitamin $\mathrm{D}$ activities found both in the idiopathic hypercalcaemic patients and the controls of this series are what would be expected from the vitamin $D$ intakes of the children as calculated from the available information on the foods and vitamin supplements given to them. The results obtained agree with those reported by Thomas et al. (1959) for two mildly affected patients (R. G. Mitchell, 1962, personal communication) but differ markedly from those of Fellers \& Schwartz (1958a,b) and Smith et al. (1959). The last two groups of workers reported high serum vitamin $D$ activities in their hypercalcaemic patients (all of the severe type). My own observations do not support their hypothesis that an abnormality of vitamin $\mathrm{D}$ metabolism associated with an increase in serum vitamin $\mathrm{D}$ activity is a necessary prerequisite for the disease, though it may sometimes be so. A more likely explanation is an abnormal sensitivity in these patients to the toxic effects of vitamin D or an abnormality in calcium metabolism not caused by vitamin $\mathrm{D}$. However this may be, the results show that in this series of patients the disease could not be attributed either to an unusually high intake of vitamin $\mathrm{D}$ or to an unusually high plasma vitamin $\mathrm{D}$ activity.

\section{SUM MAR Y}

I. The plasma vitamin $\mathrm{D}$ activities of a series of eleven children suffering from idiopathic hypercalcaemia (five with the severe and six with the mild form of the disease) were found not to be significantly elevated in comparison with values determined at the same time on plasma samples from healthy children of like sex and age.

2. The vitamin $D$ content of the liver of a patient dying with idiopathic hypercalcaemia was found to be lower than that of the liver from a control patient not suffering from any derangement of calcium or vitamin D metabolism.

I gratefully acknowledge the assistance of Dr J. A. Black, Professor D. V. Hubble, Dr M. C. Joseph, Dr R. Lightwood, Dr J. C. Macaulay, Dr R. G. Mitchell, Dr A. P. Norman, Dr K. Rhaney, Dr B. E. Schlesinger, Dr W. C. Smallwood, Dr R. H. Wilkinson and Dr B.S. B. Wood, who provided the plasma samples or permitted them to be obtained. I also wish to thank Mr G. W. Flynn and Mrs P. Charles for technical assistance. 


\section{REFERENCES}

Devaney, G. M. \& Munsell, H. E. (1935). F. Home Econ. 27, 240.

Fellers, F. X. \& Schwartz, R. (1958a). Amer. F. Dis. Child. 96, 476.

Fellers, F. X. \& Schwartz, R. (1958b). New Engl. med. F. 259, 1050.

International Union of Pure \& Applied Chemistry (1959). A Report on the Vitamin D Bioassay of Oils and Concentrates. London: Butterworths.

Morgan, H. G., Mitchell, R. G., Stowers, J. M. \& Thomson, J. (1956). Lancet, i, 925.

Quarterman, J., Dalgarno, A. C. \& Adam, A. (1963). Biochem. F. 86, x P.

Rhaney, K. \& Mitchell, R. G. (1956). Lancet, i, I028.

Smith, D. W., Blizzard, R. M. \& Harrison, H. E. (1959). Pediatrics, Springfield, 24, 258.

Thomas, W. C., Morgan, H. G., Connor, T. B., Haddock, L., Bills, C. E. \& Howard, J. E. (r959). J. clin. Invest. 38, 1078.

Warkany, J. (1937). Biochem, Z. 293, 415.

Warkany, J., Guest, G. M. \& Grabill, F. J. (1942). J. Lab. clin. Med. $27,557$. 